\title{
Tailings Pile Seepage Model The Atlas Corporation Moab Mill Moab, Utah
}

January 9, 1998

Prepared for the U.S. Nuclear Regulatory Commission Washington, D.C. 20555

Prepared by Oak Ridge National Laboratory Environmental Technology Section 2597 B 3/4 Road Grand Junction, Colorado 81503 


\section{Table of Contents}

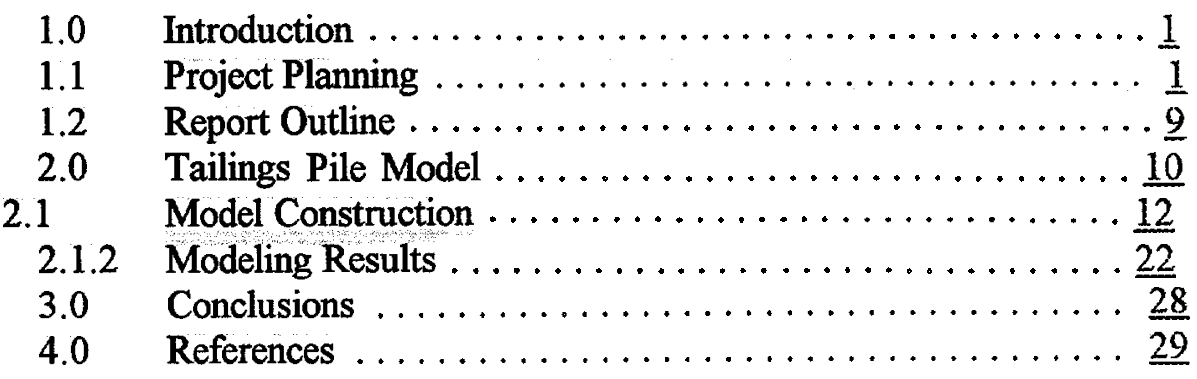

Attachment 1 Initial letter proposal prepared by ORNL/GJ

Attachment 2 Final letter proposal prepared by ORNL/GJ

Attachment 3 Seepage Model Statement of Work prepared by NRC 


\subsection{Introduction}

The project described in this report was conducted by personnel from Oak Ridge National Laboratory's Grand Junction Office (ORNL/GJ). This report has been prepared as a companion report to the Limited Groundwater Investigation of the Atlas Corporation Moab Mill, Moab, Utah. The purpose of this report is to present the results of the tailings pile seepage modeling effort tasked by the U.S. Nuclear Regulatory Commission (NRC).

\subsection{Project Planning}

The first phase of project planning occurred September 9 in a meeting in the National Park Service (NPS) offices in Moab, Utah. Attendees included representatives from ORNL/GJ, National Park Service (NPS), U.S. Fish and Wildlife Service (FWS), the State of Utah (by phone) and the Grand Canyon Trust. The discussion focused on potential effects of groundwater discharge to the Colorado River. The concern was prompted by the results of recent "grab" samples of river water collected by personnel from the State of Utah. Those samples had shown ammonia, presumably related to the tailings pile. Accordingly, ORNL/GJ was tasked with developing a sampling scheme to more accurately delineate the content, width, and transport rate of the contaminant plume. A letter proposal was distributed September 19 and is included as Attachment 1.

On October 23,1997, ORNL/GJ attended a meeting convened at the FWS offices in Denver, Colorado to address the status of the proposal. Present at the meeting were staff members from FWS, Nuclear Regulatory Commission (NRC), Atlas Corporation, Harding Lawson Associates, and ORNL/GJ. Personnel from FWS indicated that the Council on Environmental Quality (CEQ) had approved the original proposal and that the purpose of the meeting was to negotiate any remaining issues. Additionally, it was stated that any change in scope to the proposal would require approval by the CEQ. During the task review and discussion, ORNL/GJ agreed to perform the field work and to provide a report in a 60-day time frame. At adjournment, the group consensus was for ORNL/GJ to submit a revised proposal to the CEQ to seek approval for changes in scope discussed at the meeting. The revised ORNL /GJ letter proposal was distributed on October 29,1997 and is included as Attachment 2.

The ORNL/GJ proposal presented five tasks that were formulated at the Moab meeting in early September. The tasks were then refined after the Denver meeting. The tasks and the changes in scope are summarized 
below:

Task A: $\quad$ Monitoring well installation: Installing a monitoring well through the pile to determine the connection between the tailings and the underlying water table. The purpose of this task was to confirm or deny the presence of tailings or slimes within the alluvial deposits under the tailings pile. Changes in the scope for this task included the installation of two boreholes in lieu of the monitoring well, the use of a more expensive drilling method to accommodate site conditions, and analytical costs for soil samples previously not included.

Task B: $\quad$ Plume delineation: The purpose of this task was to delineate the lateral extent of groundwater contamination emanating from the tailings pile. These data were subsequently used to locate the temporary piezometers proposed to evaluate groundwater quality where it discharges to the Colorado River (Task C). Changes in scope for this task included the addition of analytical costs which were originally to be covered by the State of Utah. Additionally, an equipment mobilization charge was added to cover the costs of mobilizing ORNL/GJ equipment that was required to satisfy the schedule.

Task C: $\quad$ Evaluate riverside water quality in the groundwater: The objective of this task was to provide groundwater quality data adjacent to the Colorado River so that the flux of contamination into the river could be calculated. Changes in scope for this task were the addition of analytical costs.

Task D: $\quad$ Install new reference well north of Atlas property. This task was originally included to alleviate continuing questions regarding the background water quality. Although Atlas's current background well is located in close proximity to a former ore storage area, the proposed well was regarded as sufficiently upgradient, but felt to be in a different flow system by NRC and Atlas. Discussions regarding a new background well on Atlas property were entertained but specification of the NRC licensee's new background well was determined to be beyond the scope for FWS and ORNL/GJ. However, it was agreed that the originally proposed location would serve as a new "reference well" to establish ground water quality between the Atlas site and Arches National Park.

Task E: $\quad$ Modeling seepage from the pile: The original objective of this task as proposed by ORNL/GJ, was to provide a simple analytical solution to pile seepage using previously collected data. However, during the October 23 meeting, NRC indicated that a numerical solution using an unsaturated code would be of greater benefit and would be pursued with 
DOE's Grand Junction office. However, the following day NRC requested ORNL/GJ to prepare the model. ORNL/GJ proposed using a proprietary code (PORFLOW TM) capable of modeling saturated and unsaturated flow. Ensuing discussion with NRC limited the task to a steady-state calculation of water movement through the tailings pile as a function of recharge by precipitation. A copy of the final scope of work as drafted by the NRC is included as Attachment 3.

On November 10,1997 ORNL/GJ received budget authorization to proceed with the work outlined in Tasks A through D. Funding was provided by the U.S. Department of Energy (DOE) at the request of the CEQ. On November 18,1997, ORNL/GJ received the NRC statement of work and request for a technical and cost proposal for the modeling task (Task E). At that time, NRC requested that ORNL/GJ immediately begin work under an existing task order prior to NRC acceptance of the technical and cost proposal. Because the NRC statement of work for a tailings pile seepage model was different from the ful-scale numerical simulation discussed at the Denver meeting, ORNL/GJ requested clarification and did not begin work immediately. Following additional discussion between NRC and FWS, ORNL/GJ was directed by $\mathrm{NRC}$ to perform the modeling as presented in the original NRC statement of work. The net result was a several week delay before ORNL/GJ could focus the modeling effort.

\subsection{Report Outline}

This report presents the findings for Task E only. The results of Tasks A through D are presented in the previously referenced companion report-- Limited Groundwater Investigation Report prepared by ORNL/GJ. The following sections describe how the modeling effort was performed including modeling assumptions, construction of the flow model, calibration, and results. Attachment 3 contains the modeling scope of work provided to ORNL/GJ by NRC.

\subsection{Tailings Pile Model}

A two-dimensional groundwater flow model was constructed of the tailings pile and underlying groundwater system using the code PORFLOW TM (Analytic \& Computational Research 1994). The goal of the modeling, as requested by the $\mathrm{NRC}$, was to determine the recharge rate through the cover and tailings pile under steady-state conditions. Because the requested calculation is a mass balance problem and because recharge rates are dependent upon an assumed infiltration rate, the model provides no confirmation 
of an analytical calculation based upon Darcy's Law. In fact, if the model results do not match the analytical results, then there is a problem with the model.

The model constructed for the tailings pile and groundwater system will be useful for future predictions of contaminant transport, desaturation of the tailings pile, transient predictions of contaminant mass flux from the tailings pile to the groundwater, and the subsequent discharge of contaminants from the groundwater system to the Colorado River. In addition, the model could be used to predict the time required for the pile to desaturate and for static equilibrium or steady-state conditions to be established.

Previous work, reviewed to obtain moisture characteristic curves for tailings, does provide some insight regarding the time required for present transient conditions to reach steady-state. Klute and Heerman (1978) constructed simulations for drainage of uniform $1 \mathrm{ft}$ soil columns of fine, medium, and coarse grain tailings materials without evaporation until static equilibrium conditions were reached. From their results, the times of drainage required to reach equilibrium were estimated. These times were 100-150 days, 10002000 days, and 10000 days or more for the three soil types (Klute and Heerman 1978). Considering that the thickness of the fine-grained tailings in the Atlas pile exceeds 80 feet in some areas, it may require as much as several thousand years for the tailings to drain completely.

The following subsections discuss the construction of the flow model, calibration runs, and the results of the steady-state simulations.

\subsection{Model Construction}

A two-dimensional version of PORFLOW TM was used to conduct the simulation of water movement in the cover, tailings and underlying groundwater system. The model was separated into four layers

consisting of an upper sand cover, a clay cover, the tailings, and the underlying alluvial aquifer (Fig. 1). A basal fine-grain, slime unit was not incorporated into these simulations due to a lack of time and information on the unsaturated hydraulic properties. It is recommended for future simulations, that the model be modified to incorporate this unit because perched water zones present within the pile may be the result of low permeability exhibited by the slimes.

Boundary conditions consisted of mixed conditions of constant head or flux boundaries. The lateral boundaries consisted of constant head values for the alluvial aquifer immediately upgradient of the tailings pile and the river elevation downgradient of the pile. The lateral boundaries above the water table were set 
m小

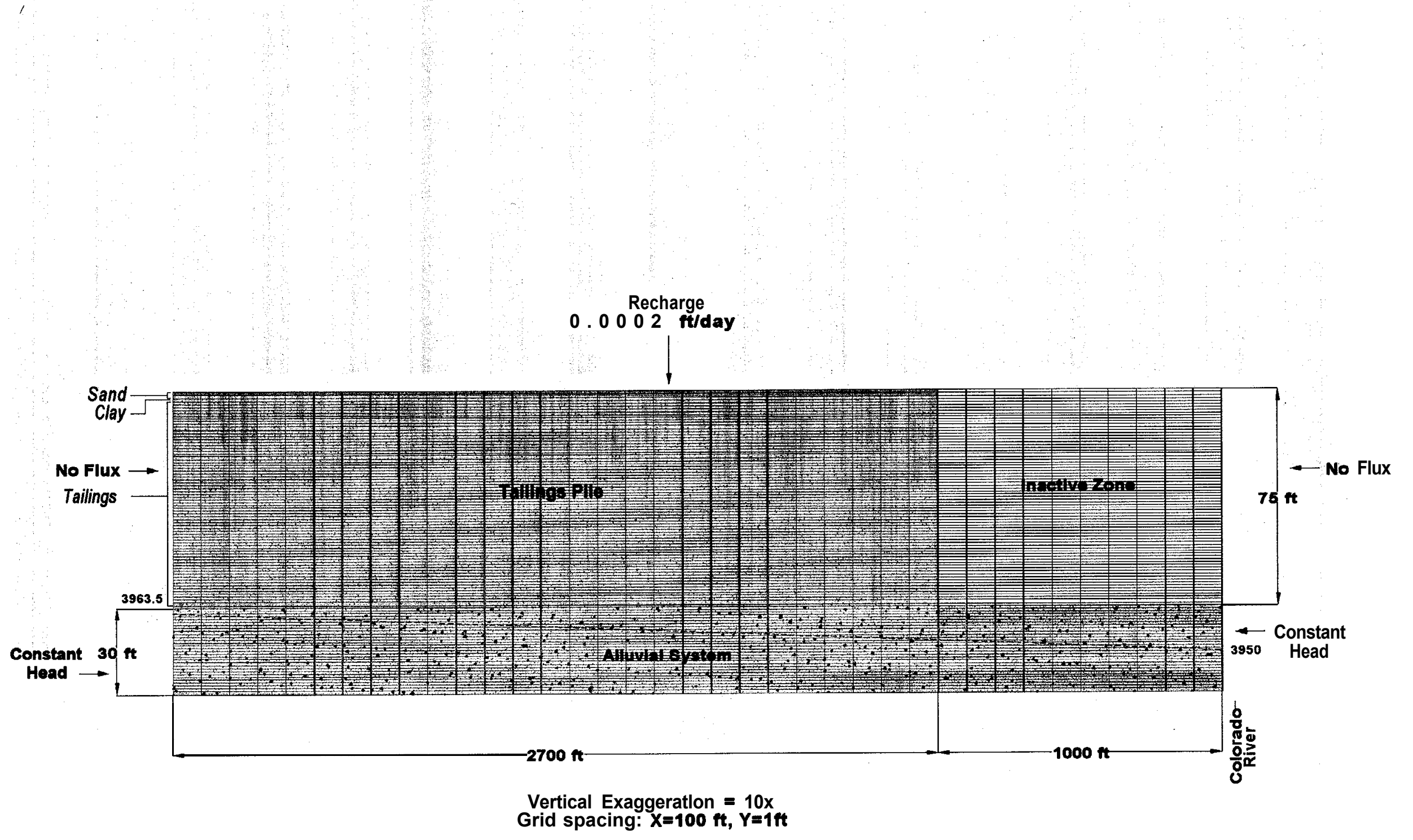

Fig. 1. Model domain for flow simulations. 
as "no flux" boundaries. Head values for these boundaries were based on water-level measurements from monitoring wells or surveyed river elevations taken during December 1997. The lower boundary, which was also set as a "no flux" boundary, may not be completely accurate considering the evidence of vertical flow from the underlying salt formations as indicated by the elevated chloride concentrations downgradient of the pile (See companion report). Nevertheless, any vertical flow should have little impact on transport calculations through the cover and pile. The upper boundary was set as a fixed flux value that corresponds to the estimated yearly infiltration rate. For steady-state simulations, this value was estimated to be $0.0002 \mathrm{ft} / \mathrm{yr}$ based on a fixed percentage of the average yearly rainfall of $8 \mathrm{in} / \mathrm{yr}$ (Blanchard, 1990). This recharge rate, resulting from precipitation, is an estimate and is open to a wide range of interpretations.

Because hydraulic conductivity values exceed the estimated infiltration rate, unsaturated flow conditions will be dominant in the cover and tailings pile. Consequently, a series of representative unsaturated hydraulic characteristic data were selected for the soils, tailings, and aquifer materials. For this report, all moisture contents will be reported in degree of saturation (volume of water divided by the void volume).

Based on geologic logs from Dames and Moore (1981), and recent borings drilled through the pile by ORNL/GJ, the tailings consist dominantly of fine-grain sand. Klute and Heerman (1978) published a series of moisture characteristic curves (pressure head or matric potential as a function of the volumetric water content) and unsaturated hydraulic conductivities as a function of moisture content. Both curves for finegrain uranium tailings (drying curve for the moisture characteristics) are presented in Figs. 2 and 3. Data from these curves were incorporated into the model to describe the unsaturated hydraulic properties of the fine-sand tailings.

For the sand cover and the underlying alluvial aquifer, a representative moisture characteristic curve was selected from a series of curves published by Bumb et al.(1992). Unsaturated hydraulic conductivity as a function of moisture content was determined using Van Genucten's original method (1978). These curves are presented in Fig. 4. Also, a representative curve for clay (Bumb et.al.(1992), typical of materials used to construct clay caps, was input into the model in a fashion similar to the other unsaturated hydraulic characteristic curves.

The unsaturated hydraulic conductivity as a function of moisture content was calculated based on texture and other soil properties presented in Wosten and Van Genuchten (1988). These curves are presented in Fig. 5. Saturated hydraulic conductivity $\left(10^{-7} \mathrm{~cm} / \mathrm{s}\right.$ or $\left.0.0003 \mathrm{ft} / \mathrm{d}\right)$ was based on the cover design for compacted clay from Klondike Flats as reported by the NRC (1997). In addition, a saturated hydraulic conductivity for the clay cover of $10^{-8} \mathrm{~cm} / \mathrm{s}$ or $0.00003 \mathrm{ft} / \mathrm{d}$, as requested by the $\mathrm{NRC}$, was also simulated. 


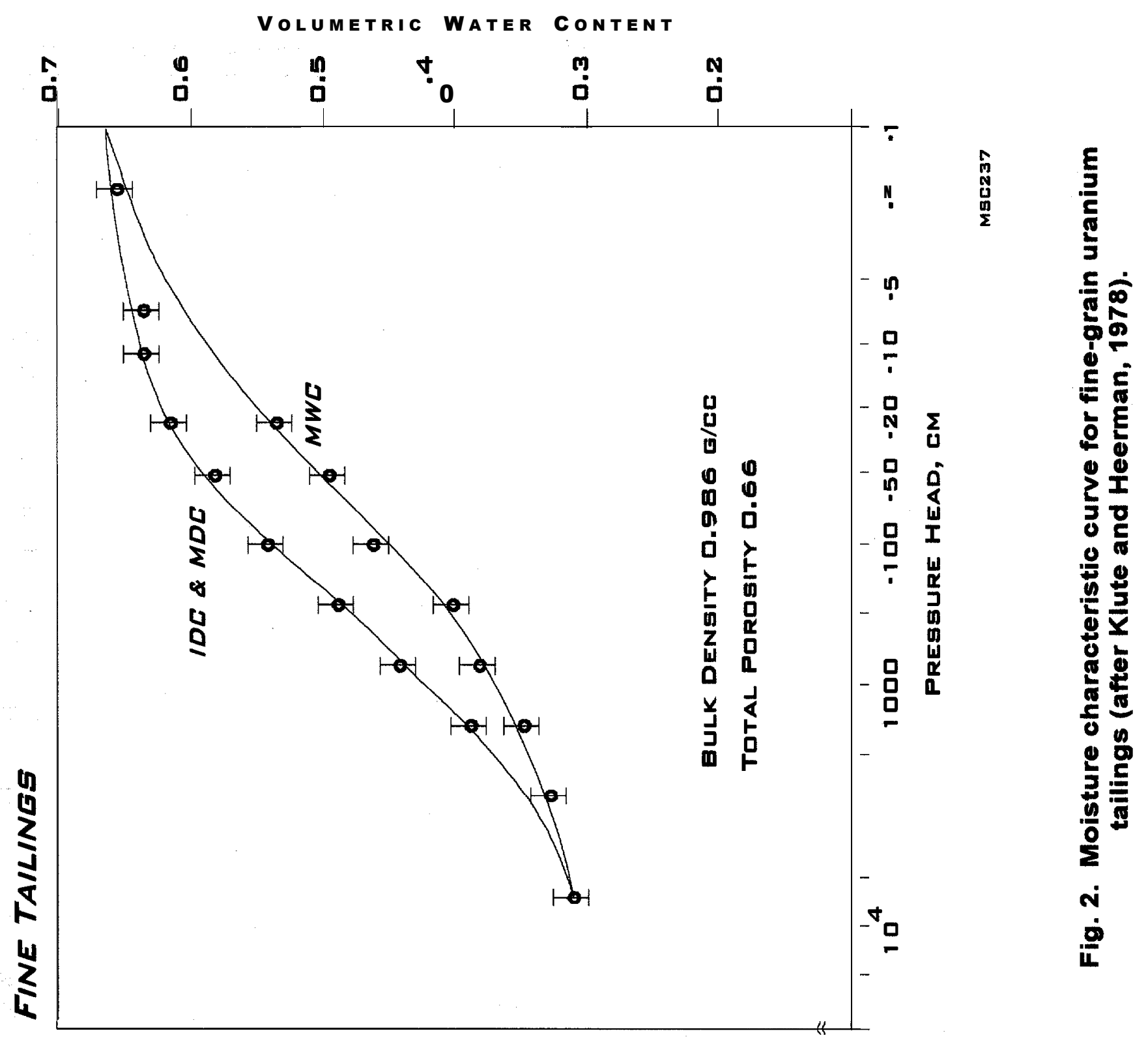




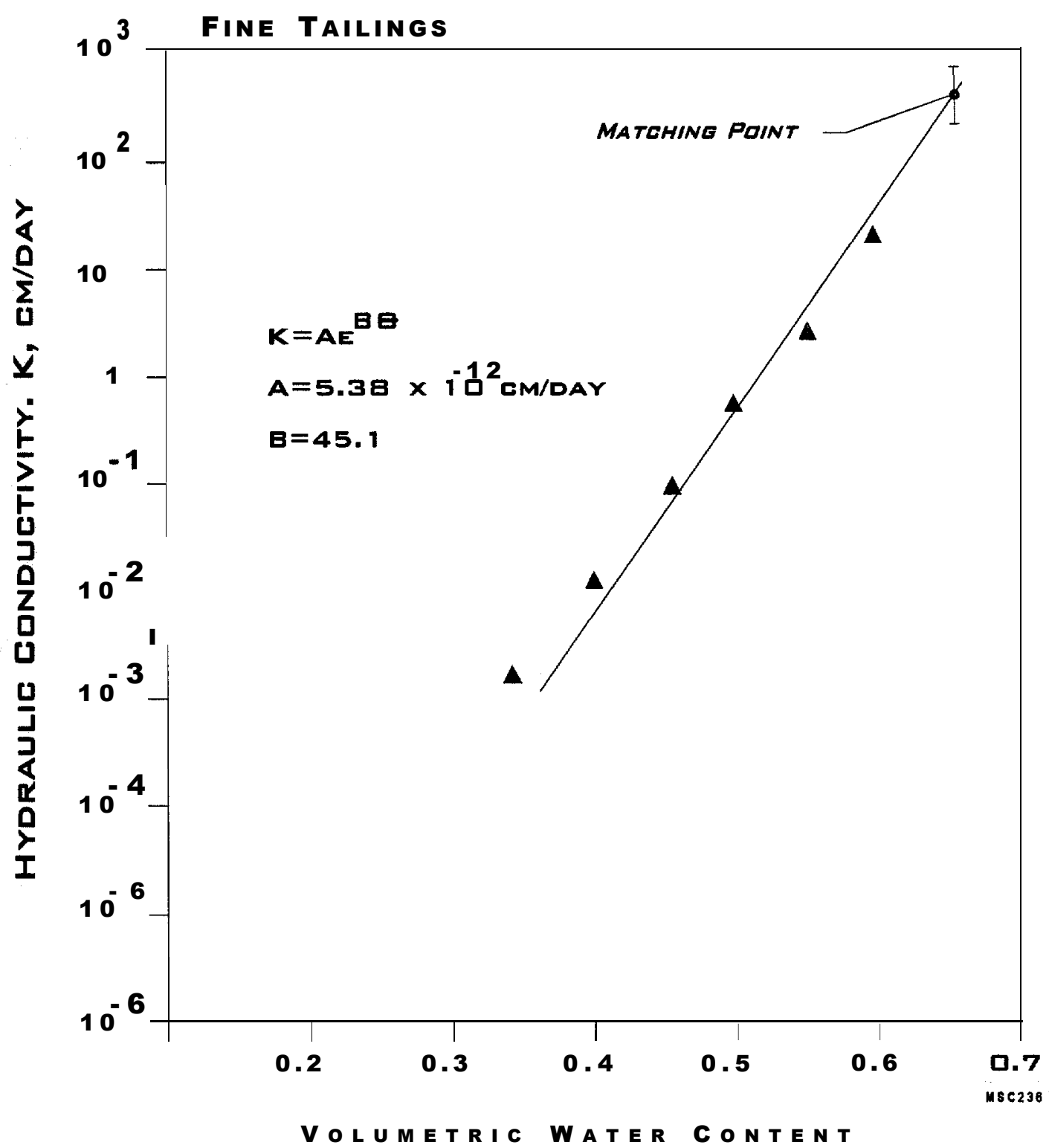

Fig. 3. Unsaturated hydraulic conductivity as a function of water content for fine-grain tailings (after Klute and Heerman, 1978). 


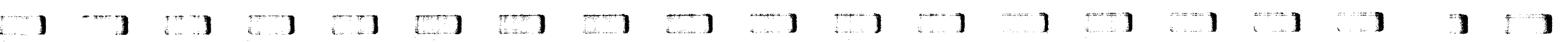
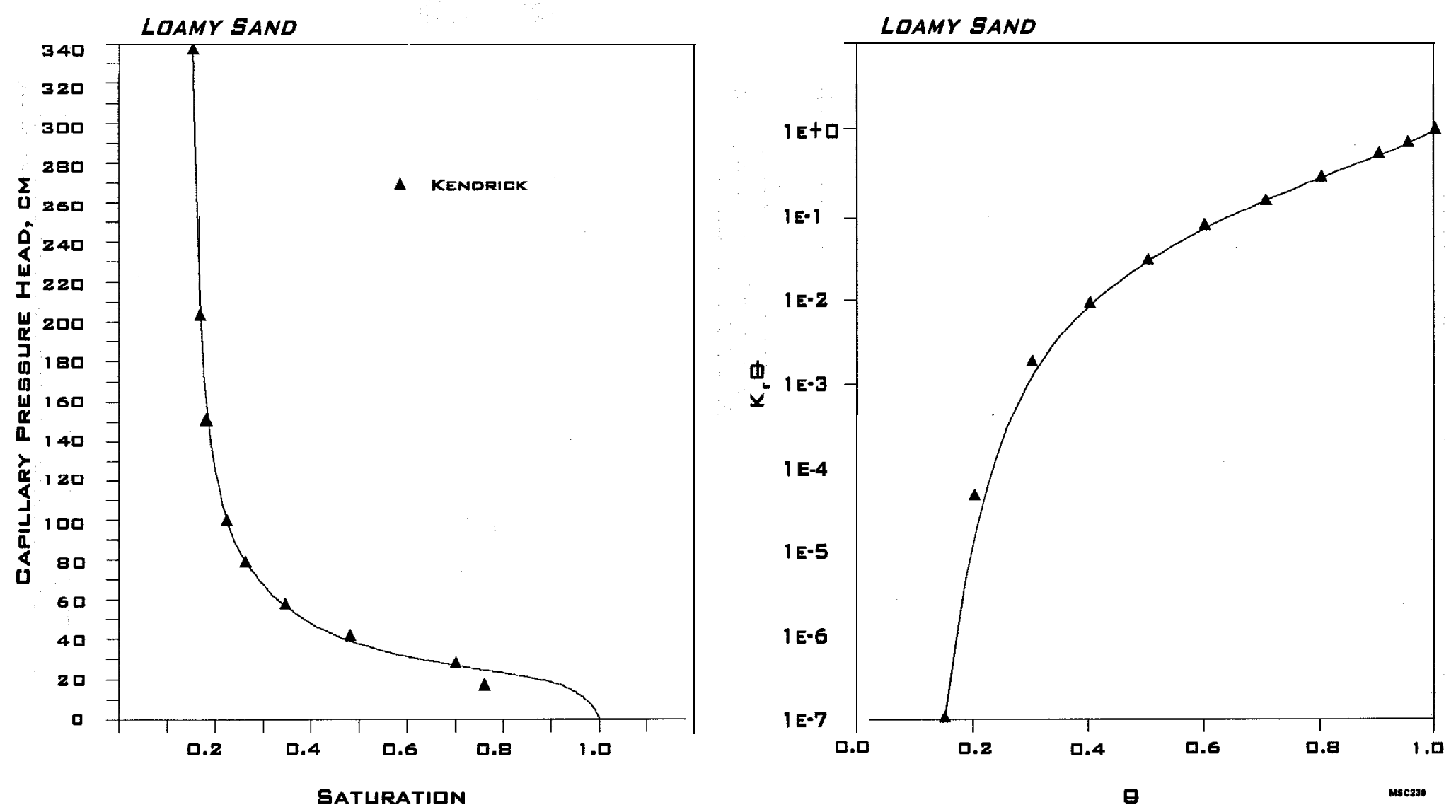

Fig. 4. Moisture characteristic curve and unsaturated hydraulic conductivity as a function of moisture content for a selected sand (after Bumb et. al, 1992). 

$E 1$ $-1 \quad \cdots 1$

FINE TEXTURED SUIL: 013

$$
\text { OLAY (\%) 56.8 }
$$

OREANIE MATTER (\%) 1.7
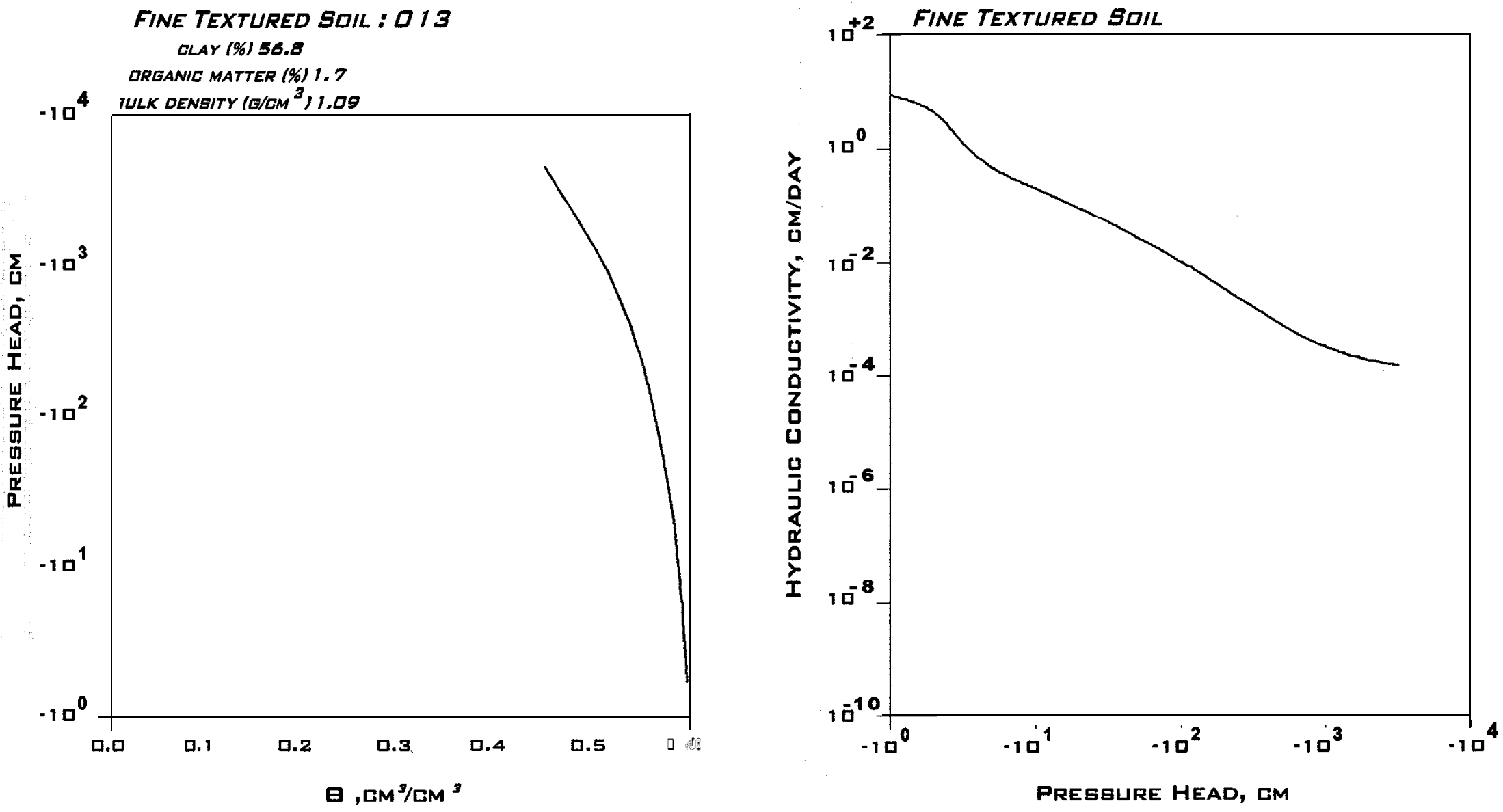

Fig. 6. Moisture characteristic curve and unsaturated hydraulic conductivity as a function of moisture content for a selected clay (after Bumb et. al, 1992). 
For numerical convergence, initial conditions consisted of setting the initial pressure through the problem domain at $-0.030 \mathrm{ft}$ which corresponded to a moisture content of 0.99 (degree of saturation). The model was run under steady-state condition, until numerical convergence met criteria.

\subsubsection{Modeling Results}

Water levels calculated by the model were compared to the potentiometric map shown in Fig. 6. Because wells completed in the alluvial aquifer underneath the tailing piles were not allowed, although recommended, water levels near the upgradient and downgradient edges of the pile had to be compared for calibration purposes. In these areas, there is good agreement between the actual and predicted water levels. Well ATP-3, located approximately 300 feet orthogonally from the upgradient edge of the pile, yielded a water level of 3995.13. At the upgradient edge of the pile, the model predicted a water level of $3963 \mathrm{ft}$ which is sufficiently accurate considering the distance and the hydraulic gradient. Downgradient of the pile, well ATP-2-S yielded a potentiometric value of $3953.77 \mathrm{ft}$ compared with $3955.5 \mathrm{ft}$ for the model.

Comparisons of residual moisture content (defined as the moisture content where water no longer moves under the forces of gravity or capillarity) for the cover and tailings material were also evaluated. For the sand covering the pile, the moisture characteristic curve shows a degree of saturation of 0.15 at the residual moisture content. At steady-state conditions, the model also calculates a moisture content of 0.15 after all of the water has drained from the soil. The clay cap moisture characteristic curve shows a residual moisture content of 0.71 . The model calculates a moisture content of 0.71 . For the underlying sand tailings, the model predicts that the moisture content ranges from 0.63 just below the clay cap to 0.75 at the base of the pile. At the lower moisture range in the tailings, the unsaturated hydraulic conductivity is sufficient to conduct the total volume of recharge through the pile.

As expected, the recharge rate through the cover $\left(K=10^{-7} \mathrm{~cm} / \mathrm{s}\right.$ or $\left.0.0003 \mathrm{ft} / \mathrm{d}\right)$ and the tailings matches the infiltration rate of $0.0002 \mathrm{ft} / \mathrm{d}$. This is expected because the unsaturated hydraulic conductivity of the clay unit, which exhibits the lowest permeability of the simulated lithologic units, exceeds the recharge rate. Consequently, the recharge rate controls the flow rate in the cover and tailings pile. To calculate the recharge to the underlying groundwater system directly from the pile, the surface area of the pile is multiplied by the recharge rate. A GPS survey of the tailing pile surface area (see companion report) resulted in a value of $3868100 \mathrm{ft}^{2}$ which yields a total discharge of water from the pile, resulting from precipitation, to the groundwater of $3.7 \mathrm{gpm}$. 


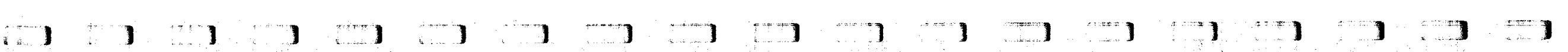

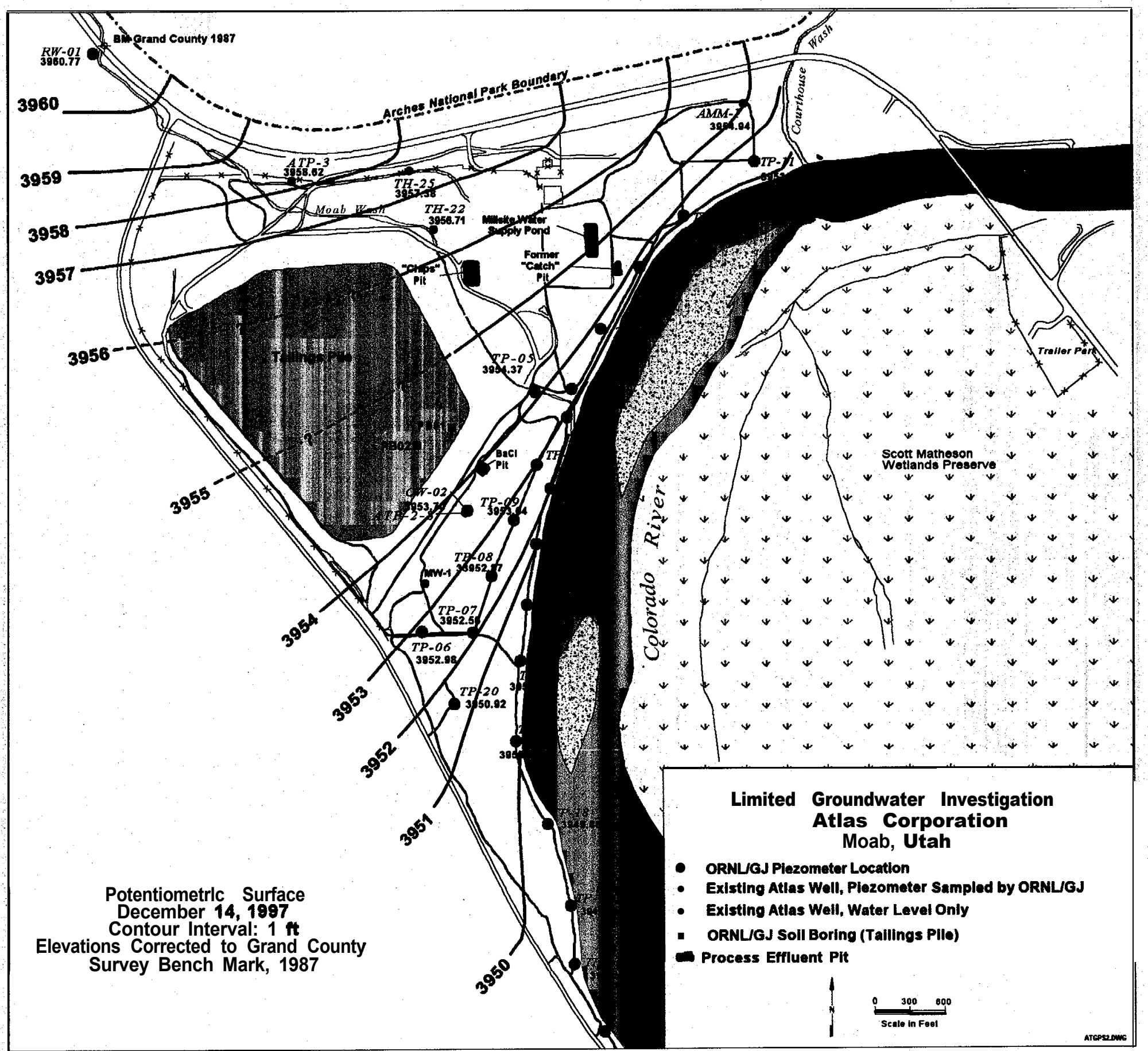

Fig. 6. Potentiometric surface map for shallow alluvial aquifer, December 14, 1997. 
Simulations were also conducted to estimate the amount of water that could pass through the pile with a clay cap exhibiting a saturated hydraulic conductivity of $10^{-8} \mathrm{~cm} / \mathrm{s}$ or $0.00003 \mathrm{ft} / \mathrm{d}$. Numerical problems were encountered by attempting to simulate an infiltration rate higher than the saturated hydraulic conductivity of the clay. Initial attempts at refining the model grid showed the flux rate approaching the saturated hydraulic conductivity of the clay. Due to time constraints imposed by the delayed start of the modeling effort, a complete sensitivity analysis of the model to eliminate the numerical problem was not possible. It appears, however, that the infiltration rate will match the clay's saturated hydraulic conductivity of $0.00003 \mathrm{ft} / \mathrm{d}$. Using the surface area of the pile $\left(3868100 \mathrm{ft}^{2}\right)$, therefore, the discharge of water from the tailings pile is $0.6 \mathrm{gpm}$ for the lower hydraulic conductivity value.

\subsection{Conclusions}

The results of the numerical model simulations of steady-state water movement through the tailings pile at Moab, Utah showed that precipitation and subsequent infiltration rates control the flux of water into the underlying groundwater system. Modeling simulations for a saturated hydraulic conductivity of $10^{-7}$ $\mathrm{cm} / \mathrm{s}$ yielded a flux value of $0.0002 \mathrm{ft} / \mathrm{d}$. Although numerical problems are encountered with modeling $10^{-8}$ $\mathrm{cm} / \mathrm{s}$, a flux of $0.0003 \mathrm{ft} / \mathrm{d}$ was inferred. These data result in a discharge rate of water from the tailings to the underlying groundwater system of $3.7 \mathrm{gpm}$ for $10^{-7} \mathrm{~cm} / \mathrm{s} \mathrm{K}$ value and $0.6 \mathrm{gpm}$ for the $10^{-8} \mathrm{~cm} / \mathrm{s} \mathrm{K}$ value. As noted earlier, however, these modeling results do not provide independent confirmation of an analytical calculation based upon Darcy's Law. For additional discussion on the contaminant transport, the reader is referred to the companion report--Limited Groundwater Investigation Report prepared by ORNL/GJ.

\subsection{References}

Analytic \& Computational Research. 1994. PORFLOW Validation. Version 2.50. A software tool for multiphase fluid flow, heat, and mass transport in fractured porous media. Analytic \& Computational Research, Inc. Bel Air, California, 90077.

Blanchard, Paul J.1990. Ground-Water Conditions in the Grand County Area, Utah, With Emphasis on the Mill Creek-Spanish Valley Area. Technical Publication No.100, State of Utah, Department of Natural Resources. Prepared by the United States Geological Survey in cooperation with the Utah Department of Natural Resources Division of Water Rights. 
Bumb, A.C., C. L. Murphy, L. G. Everett. 1992. A comparison of three functional forms for representing soil moisture characteristics. Ground Water, Vol. 30, No. 2, pp. 177-185.

Dames \& Moore 1981. Report of Engineering Design Study Additions to Tailings Pond - embankment System. Moab, Utah for Atlas Minerals. Job No. 5467-018-06. February 15, 1978. New printing May 26, 1981.

Klute, A., and D. F. Heerman. 1978. Water movement in uranium tailings profiles. Tech. Note, ORP/LV/78-8, EPA Office of Radiation Programs, Las Vegas, NV.

Nuclear Regulatory Commission. 1997. Final Technical Evaluation Report for the proposed revised reclamation plan for the Atlas Corporation Moab Mill; Source Material License No. SUA-917. NRC, Docket No. 40-3453, Washington D. C.

Van Genuchten, R.. 1978. Calculation the unsaturated hydraulic conductivity with a new closed-form analytical model. 78-WR-08, Dept. of Civil Eng., Princeton Univ., Princeton, NJ.

Wosten, J.H. M., and M. TH. Van Genuchten. 1988. Using texture and other soil properties to predict the unsaturated soil hydraulic functions. Soil Science Society of America Journal, Vol.52, No. 6 , 1762-1770. 


\section{September 17, 1997}

Mr. R. Bruce Rodgers

Chief Division of Resource Management

National Park Service

Department of the Interior

2282 S. West Resource Blvd.

Moab, Utah

84532

- Dear Bruce:

Enclosed please find the requested information regarding our proposed work at the Atlas Millsite. The first attachment is an annotated task list and cost estimate for the work. We. haye separated the work into specific tasks such that you can prioritize them if necessary. In addition, we have added narrative discussion to describe the expected benefit from the proposed work along with some pros and cons. Note our assumption, based on the September 9, 1997 meeting, that the State of Utah will provide the laboratory analytical support. We can provide the laboratory support at additional cost if necessary.

The second attachment is some-descriptive material on our group. Our emphasis has been to solve hydrologic and sampling problems that are typically beyond that provided by private contractors. We have also been-at the forefront of developing and using on-site analytical capability - although such an approach is now relatively common.

For your information, two grab samples of surface water were collected when the reconnaissance trip was performed on September 15, 1997. River stage was estimated by Park Service personnel in attendance at approximately 8,000 cfs. Our sample from a seepage face (surface flow) in Moab wash contained $3580 \mathrm{ppm}$ sulfate and $190 \mathrm{ppm}$ ammonia (as $\mathbf{N}$ ). A sample collected from the river's edge at the confluence of the wash and the river contained $437 \mathrm{ppm}$ sulfate and $2.4 \mathrm{ppm}$ ammonia.

As I recall, early next week there will be a meeting in Washington regarding this proposed work. I will be out of the office- Monday through Wednesday but Frank Gardner will be able to answer any questions. In addition, please keep us appraised of developments regarding timing and funding. If we have advance notice, we can - ensure that the necessary equipment and personnel are available and, more importantly, we can facilitate the 
- Mr. R. Bruce Rodgers

2

September 17, 1997

movement of funds by alerting various people within the DOE system. The latter activity can often save a month or more in initiating a project.

- If you have any questions, please feel free to call either me (970-248-6210) or Frank Gardner (970-248-6238) who will manage and direct the field work.

3

Sincerely,

\section{Nic Korte}

- Group Leader, Restoration Technology

NEK:kah

\section{Enclosures}

c: F. G. Gardner (w/o attachment 2)

D. K. Halford (w/o attachment 2)

B. Hedden (w/o attachment 2)

B. H. Waddell (w/o attachment 2) 


\section{Attachment 1 - Description of Proposed Tasks/Cost Estimate}

Although the tasks below are inter-related, each could be performed independently. Thus, the cost estimate is provided on a task-by-task basis. A final report is not shown as a specific task but is included in the cost estimate through the project management functions. That report will encompass all of the tasks and include all documentation that is typically expected for a project of this type;

\section{Task A: Installing a well through the pile to determine the connection between the tailings and the underlying water table.}

Drilling through a waste site is often avoided because of the fear of cross-contamination. Unfortunately, drilling methods that provide assurance that cross-contamination cannot occur make sampling diicult and expensive.

- We have addressed this problem on numerous occasions and have provided two approaches for the Atlas site. Our preferred approach is to use a conventional auger rig. Hollow-stem augering with a continuous sampler provides the best samples and will yield the most assurance in determining the tailings/water table interface. Augering will cause a small amount of cross-contamination but the quantity will be incidental and dwarfed by the amount of contamination already leached (and continuing to leach) through the pile.

An alternate approach is to use a dual-wall, reverse-circulation air rotary rig instead of augering. With this method, we can prevent cross-contamination but drilling and sampling are more expensive - approximately double the cost of using a hollow-stem auger. Our experience, however, has shown that the cost and time required for the dual-wall approach is not justified for a site such as this. Whichever drilling method is used, the visual and analytical data will be augmented with borehole gamma logging to verify the results fi-om other measurement and visual techniques. In addition, in either case, the well will be constructed such that there will not be a conduit for cross-contamination down the borehole.

The attached cost estimate for this task assumes, a, single, 150-R well on the pile. Additional wells would cost approximately $20 \mathrm{~K}$ each. If the dual-wall method were needed, the drilling cost shown in the cost estimate would increase from $12 \mathrm{~K}$ to $24 \mathrm{~K}$.

Before drilling is initiated, existing data (photos, maps) will be reviewed extensively in order to determine the optimum location for the well(s).

Pros:

1) Provides direct observation of the relationship of the water table and the base of the tailings.

Cons:

1) Expensive.

2) Requires equipment not owned by ORNL. Thus, project initiation cannot be immediate because of the need to establish a drilling contract. 
3) The bottom of the pile is probably not uniform. Because only a limited number of boreholes can be drilled, the data obtained may not be conclusive.

4) Many of the tailings contaminants are mobile in oxygenated groundwater. Leaching from rainfall and the spraying on top of the pile may have redistributed considerable quantities of the contaminants to the underlying aquifer whether or not tailings lie below 'the water table. These circumstances are difficult to prove or disprove with a limited number of boreholes.

5) Health, safety, and access requirements that might be added by Atlas or NRC are unknown. Their requirements may be above and beyond ORNL rules and procedures and increase cost.

\section{Task B: Plume delineation (Fig. 1).}

Using an approximate spacing of $500 \mathrm{ft}$, we can delineate the plume with approximately 15 to 20 temporary piezometers using our small, mobile drilling rig. Two or three 2-inch permanent wells will be installed to obtain, some data regarding the hydraulic conductivity. The permanent well locations will be selected based on field observations. Existing data will be reviewed initially. *This review could result in some modification to the sampling plan. In addition, wells already present at the site may be sufficient for obtaining the necessary hydrologic data — assuming access is permitted.

Pros:

1) The width of the plume can be accurately determined while in the field using ammonia and sulfate as indicators.

2) The hydraulic connection of the plume and the river can be more accurately described.

- The hydraulic conductivity can be accurately measured.

- A potentiometric surface can be obtained that is much more accurate than those obtained previously.

(The latter two activities provide the gradient and flow rate of the plume. In addition, preferential pathways will be identified.)

3) The work can be initiated on short notice because personnel and equipment are resident in Grand Junction.

4) Subsequent analyses of the groundwater, to be performed by the State of Utah, will show which contaminants are migrating and permit a more accurate calculation of the mass flux into the river.

Cons:

1) The proposed plan would provide a limited number of permanent wells. (More of them could be installed permanently if desired.) 


\section{Task C: Evaluate riverside water quality in the groundwater.}

Seepage meters or mini-piezometers (3/4 in. ID) will be installed along the riverbank as a means of obtaining the quality of the water where it enters the river.

Pros:

1) These data will confirm (or not) the "grab" river samples collected by the State of Utah.

2) These samples will provide direct evidence of the location and quantity of contamination entering the river.

3) Rapid and inexpensive.

4) Because the sampling is through a well-casing, standard, approved sampling and analysis procedures can be used.

Cons:

None

\section{Task D: Install new background well northeast of Atlas property.}

Pros:

1) The installation of this well would alleviate continuing questions regarding the background water quality. Atlas believes that the background water has some of the same contaminants. as those contributed by the pile. However, Atlas's background well is located in close proximity to a former ore storage area. The new well would be sufficiently upgradient, yet still in the same flow system to ensure an accurate description of background water quality.

Cons:

1) ORNL's mobile rigs may not be capable of drilling this hole because the location may contain too many cobbles. To ensure successful completion of the hole, a drilling contract is necessary. (If Task A is included, drilling this well can be added easily and at relatively low additional cost.)

\section{Task E: Modeling drainage from the pile.}

This task was not discussed during the scoping meeting held in Moab. However, upon review of the data and the site, we learned that Atlas has been pumping water on top of the pile for sometime. Thus, the pile will continue to drain contaminated water even. after it is. capped. This drainage can continue for many years or even decades. Thus, we are proposing site specific calculations to show the long-term effects of the pile drainage. In other words, even if the pile is isolated from the groundwater by a cap, downward leaching of water within the unsaturated pile remains a source of contamination to the groundwater. 
- Pros:

1) Inexpensive estimate of the length of time that the pile will continue to contaminate the groundwater after capping is completed.

Cons:

None

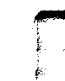

7

5

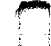

P

7

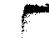

$\rightarrow$

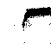

tra

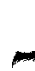

.

$\Gamma$

$+$

3 


\section{Attachment 2 - Description of ORNL Grand Junction Office Capabilities}

Appended are examples of work we have performed that is relevant to the problem posed by the Atlas Millsite.

Following those examples are some fact sheets that highlight other mill tailings related projects and the diversity of geohydrologic projects with which we have been involved. 
Attachment 2

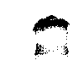

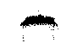

$-$

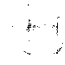

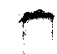

?

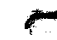

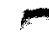

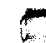

$r$

m 
2597 B 3/4 Road

Grand Junction, Colorado 81503

October 29, 1997

Mr. Reed Harris

U.S. Fish and Wildlife Service

Lincoln Plaza, Suite 404

Salt Lake City, Utah 84115

Dear Reed:

Enclosed please find the requested information regarding our revised proposed work at the Atlas Millsite. The first attachment is an annotated task list and cost estimate for the work. We have separated the work into specific tasks such that you can prioritize them if necessary. In addition, we have added narrative discussion to describe the expected benefit from the proposed work along with changes to the scope resulting from the meeting held in Denver last Thursday, October 23.

You will notice a marked increase in the attached cost estimate. This results from increasing scope of drilling activities on the tailings pile, use of more expensive drilling methods, and increased scope for the tailings pile drainage model. The latter task was included at the request of NRC following the meeting last week. Increased costs also result from a new fiscal year cost center rate which reflects an increase of $\$ 6$ per hour.

We find ourselves in a tenuous situation as the players and agendas unfold. While it is our intent to deliver the findings of the testing program with unbiased objectivity, we also feel our credibility is at risk due to factors beyond our control at this point. We made verbal commitments to a 60-day schedule last week in Denver assuming a relatively quick starting date (i.e., a week or two). However, the outstandii or unresolved issues (off site access, funding source, approval of expanded scope, etc.) looming in light of the existing commitments we have in December will require that we caveat the schedule. We will need to be activated (i.e., ORNL charge number in hand) by November 10 in order to meet the mid-January time frame for report delivery. We are hopeful that these issues will be worked through so that we may get into the field by November 10 . Please keep us appraised of developments regarding timing and funding. If we have advance notice, we can facilitate the movement of funds by alerting various people within the DOE system. 
Reed Harris

2

October 29, 1997

If you have any questions, please feel free to call either me (970-248-6238) or Nic Korte (970-248-6210).

Sincerely,

Frank Gardner

Group Leader, Characterization Technology

Environmental Technology Section

Life Sciences Division

FGG:kah

Enclosures

c: R. E. Blubaugh (Atlas Corporation),

B. M. Campbell (CEQ)

M. H. Fliegel (NRC)

D. K. Halford (ORNL)

N. E. Korte (ORNL)

M. McUsic (DOI)

G. L. Ohland (HLA)

R. B. Rodgers (NPS)

B. H. Waddell (FWS) 


\section{Attachment 1 - Description of Proposed Tasks/Cost Estimate}

Although the tasks below are inter-related, each could be performed independently. Thus, the cost estimate is provided on a task-by-task basis. A final report is not shown as a specific task but is included in the cost estimate through the project management functions. That report will encompass all of the tasks and include all documentation that is typically expected for a project of this type.

The following tasks reflect modifications resulting from a meeting held October 23, 1997 where representatives from interested parties (Atlas, NRC, FWS, and ORNL) were present.

\section{Task A: Installing borehole(s) through the pile to determine the connection between the tailings and the underlying water table.}

The purpose of this task is to confirm or deny the presence of tailings or slimes within the alluvial deposits under the tailings pile. The originally proposed well in the center of the tailings pile was changed by group consensus to a borehole to meet this objective and thus prevent the potential for a contamination conduit into the alluvial aquifer presented by a well. The presence of a pond in the center of the tailings pile may require an angled drilling approach where the rig would be better supported by drier sediments along the periphery. Following additional group discussion, a second borehole in the tailings pile was proposed to verify the validity of an earlier allegation placing tailings in the alluvium. If the review of the existing data do not support the allegation, the second borehole will not be drilled. However, the task is included in the cost estimate-at this time.

Research and discussion carried out singe the submittal of the original proposal has determined that drilling will be performed using the more expensive option (dual wall reverse circulation) for several reasons. Primarily, drilling in saturated tailings with a hollow stem auger could lead to problems associated with fine sands flowing up into the auger string. If this occurs, soil sampling and angle drilling is not feasible with hollow stem augers to the projected depth. Secondly, review of data on the alluvial composition has determined the presence of boulders and cobbles that would hinder auger drilling. Therefore, the drilling will be performed with a dual wall reverse circulation (DWRC) rig to prevent foreseeable problems associated with auger drilling. Soil samples (wire line split spoon) will be collected on $\mathbf{5} \mathbf{f t}$ intervals and the samples will be analyzed in the field for radium using ORNL's opposed crystal scanning (OCS) system. Two or three samples of the alluvial material below the tailings will additionally be analyzed for uranium (U), vanadium (V), arsenic (As), Copper (Cu), molybdenum (Mo), and selenium (Se) as an additional measure of potential slimes migration. A lithologic log of the borehole using the United Soil Classification System will be prepared by the field geologist. Based on the results of the group discussion, gamma logging of the borehole will not be performed as the tailings material should be readily distinguished from the underlying alluvium by visual examination and the OCS radium analysis. All drilling and sampling generated waste (solid and liquid) will be recharged to the top of the tailings pile. Finally, a location/elevation survey will deliver state-plane coordinate data and ground surface elevations for the borehole location(s).

The attached cost estimate for this task assumes two, 150-R boreholes on the pile using a DWRC rig. Additional line items required for site access are grouped under training /medical requirements in the cost estimate. Atlas will require approximately one half of one day for site orientation for all personnel in addition to urinalysis testing for uranium for those working directly on the tailings pile. Lastly, analytical costs were also included to cover soil sample analyses previously discussed.

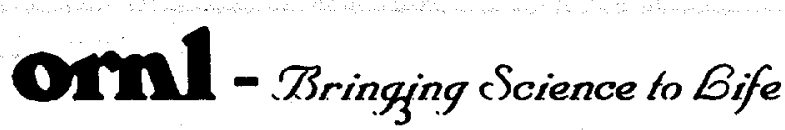


Before drilling is initiated, existing data (photos, maps) will be reviewed extensively in order to determine the optimum location for the boreholes. ORNL is working the Health and Safety issues with Atlas so that the field work can begin without delay.

\section{Task B: Plume delineation (Fig. 1).}

The purpose of this task is to delineate the lateral extent of groundwater contamination emanating from the tailings pile. These data will subsequently be used to locate the temporary piezometers proposed to evaluate groundwater quality where it discharges to the Colorado River (Task C). Locating the riverside piezometers without the lateral extent of the plume defined would be of liited benefit, Therefore, these tasks are interrelated and required to provide the comprehensive objective of the testing plan which is to assess contaminant flux into the Colorado River.

As a result of the group meeting on October 23, the first phase of plume delineation effort will begin on Atlas property as issues related to access to the adjoining private property to the south are resolved. ORNL is looking to NRC and the licensee for assistance with the property access issue as we are not in a position to negotiate with a private land owner. However, if the access issue is not pursued and the first phase of plume delineation indicates an off site problem, the comprehensive objective of the testing plan will be thwarted. Therefore, the temporary piezometers ( 1 in. OD) illustrated in Figure 1 have been grouped into two categories: those on Atlas property and those on private property. Review of existing data may result in some modification to the delineation approach by reducing the number of temporary piezometers proposed between the tailings pile and the river. Field screening parameters for plume delineation will include testing for ammonium $(\mathrm{N})$ sulfate $\left(\mathrm{SO}_{4}\right)$ alkalinity, conductivity, $\mathrm{pH}$, and temperature. Confirmatory groundwater sample analysis will be limited to $\mathrm{U}$, $\mathrm{V}, \mathrm{As}, \mathrm{Cu}, \mathrm{Mo}$, and $\mathrm{Se}$. One round of groundwater sampling is proposed. All drilling and sampling generated waste (solid and liquid) will be recharged to the top of the tailings pile. Permitting issues related to clearing of vegetative cover on the flood plain are also being resolved by FWS personnel.

As part of the plume delineation effort, two or three 2-inch permanent wells will be installed to obtain some data regarding the hydraulic conductivity of the alluvium. While ORNL recognizes that some existing data on aquifer characteristics (permeability and conductivity) has been collected in the past, we want to have utmost confidence on the basis used for groundwater/contaminant discharge calculations to the Colorado River. Additionally, use of existing hydraulic conductivity data collected using a variety of methods (slug tests and lab measurements) creates a range that can vary by an order of magnitude or more. Therefore, ORNL will collect hydraulic conductivity measurements based on pumping tests performed on the proposed two inch wells. The permanent well locations will be selected based on field observations and a review of existing data. This review could result in reducing the number of two inch wells if existing wells can be used to obtain the hydraulic conductivity data. ORNL has requested access to the most recent data from Atlas and Harding Lawson Associates. We do not have these data in hand and cannot make the necessary adjustments in the sampling plan until they are available.

Finally, a location/elevation survey will deliver state-plane coordinate data, ground surface and top of casing elevations for the piezometers and wells.

Mobilization charges for ORNL equipment (direct push drill rig) had previously not been included because it was originally felt that our equipment currently in Ohio could be brought back to Grand Junction by leveraging associated travel costs with other projects. However, in light of the uncertainty in this project schedule and the 
potential conflict with planned December field work in Ohio, a line item for mobilization has been added to the cost estimate.

\section{Task C: Evaluate riverside water quality in the groundwater.}

The objective of this task is to provide groundwater quality data as it discharges to the Colorado River. The final location of the proposed piezometers in Figure 1 will be determined by the results of the plume delineation effort. This may result in a different spacing than shown in Figure 1. As previously discussed, if access to the proposed sampling points along the river on the private property is denied, the comprehensive objective of the testing plan is jeopardized..

Temporary piezometers ( 1 in.) will be installed along the riverbank as a means of evaluating the quality of the water where it enters the river. It was agreed at the October 23 meeting that FWS personnel would coordinate permitting issues associated with the clearing of vegetation to allow access to all sampling points on the flood plain. Furthermore, as a result of the group meeting, the number of sampling points along the river bank northeast of Moab Wash has been expanded to address potential impacts to groundwater quality from milling operations. (Fig. 1). It should be noted that the riverside sampling locations northeast of Moab Wash will be located on a $500 \mathrm{ft}$ spacing and will not benefit from the plume delineation efforts associated with the other riverside piezometer locations to the southwest of Moab Wash.

Field screening parameters for plume delineation will include testing for ammonium (N) sulfate (SO, ) alkalinity, conductivity, $\mathrm{pH}$, and temperature. Confirmatory groundwater sample analysis will be limited to $\mathrm{U}, \mathrm{V}, \mathrm{As}, \mathrm{Cu}$, Mo, and Se. One round of groundwater sampling is proposed. All drilling and sampling generated waste (solid and liquid) will be recharged to the top of the tailings pile. Finally, a location/elevation survey will deliver stateplane coordinate data, ground surface and top of casing elevations for the piezometers.

Overall, the scope of this task has increased but the cumulative scope of plume delineation and riverside quality assessment remains the same as a total of 23 temporary sampling points are still being proposed between both tasks. Analytical costs have also been included in the attached cost estimate for this task.

\section{Task D: Install new reference well north of Atlas property.}

This task was originally included to alleviate continuing questions regarding the background water quality. Although Atlas's current background well is located in close proximity to a former ore storage area, the proposed well would be sufficiently upgradient, but in a diierent flow system. Discussion regarding a new background well on Atlas property was entertained but location of the NRC licensee's new background well was determined to be beyond the scope for FWS and ORNL. However, it was agreed that the proposed location would serve as a new "reference well" to establish ground water quality between the Atlas site and Arches National Park.

The cost estimate for this well also reflects. an increase, due to the selection of DWRC drilling methods for reasons previously stated. Additionally, analytical costs have also been included in the cost estimate for this task. 


\section{- Task E: Modeling drainage from the pile.}

- The original objective of this task was to provide a simple analytical solution to pile drainage using previously collected data. However, during the October 23 meeting, NRC indicated that a numerical solution using an unsaturated code would be of greater benefit and would be pursued with DOE's Grand Junction office.

- However, the most recent dialogue with NRC has ORNL preparing a the model. Therefore, the cost estimate for : this task has increased dramatically to accommodate NRC modeling requirements. ORNL is proposing to use a proprietary code (PORFLO) capable of saturated and'unsaturated flow modeling. 


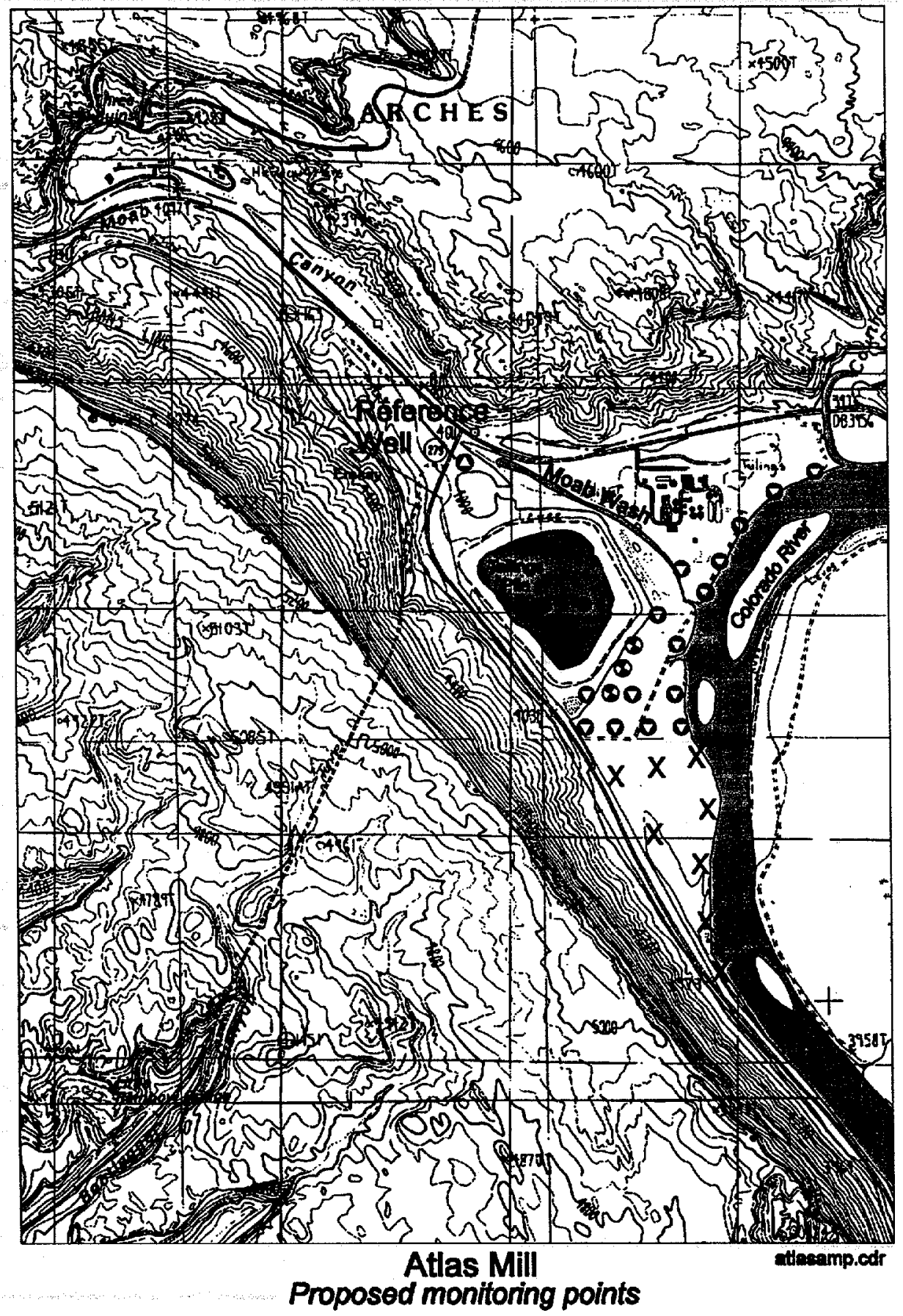

- 2" PVC Monitoring well

- Reference well

- 1" tomp. plezometors (Atlas property)

$X$ 1" tomp. plazemetere (Pivato property)

- Soll borkng 

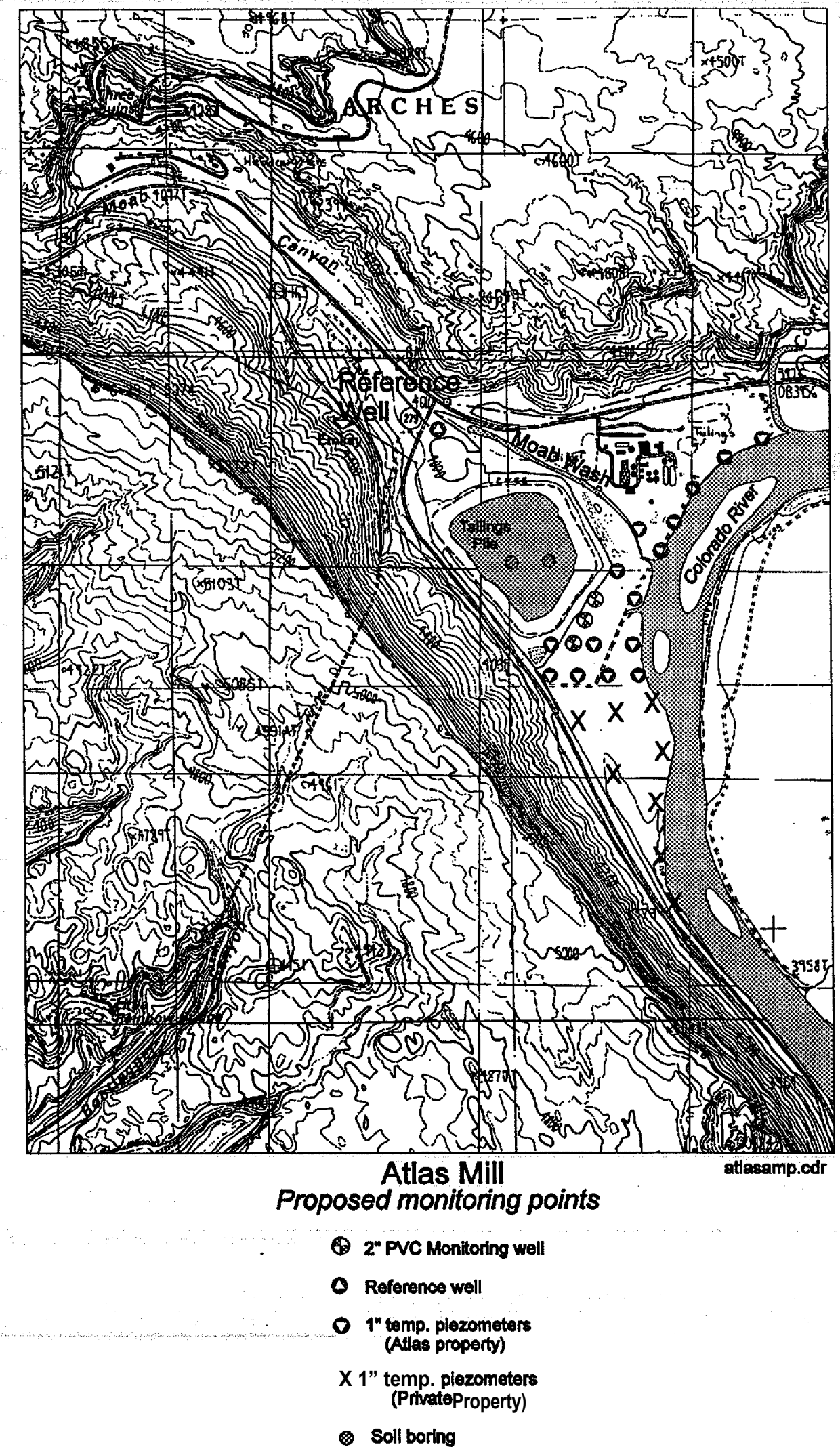
Attachment 3

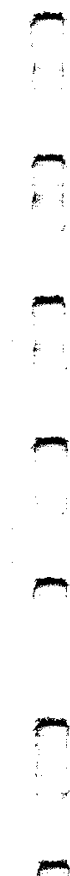

$m$ 


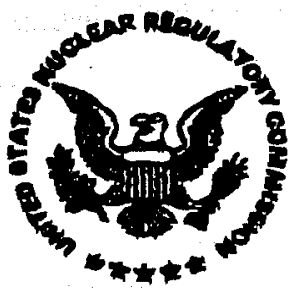

\section{UNITED BTATES}

\section{NUCLEAR RECULATOFY COMMISEION}

wathireton, B.c. arem

November 18,1997

Mr. Edward G. Cumesty

ORNL Site Manager

US. Department of Energy

Oak Ridge National Laboratory

P.0. Box 2008

Oak Ridge. Tennessee 37831-6269

SURJECT: NRC PROJECT ENT ITLED ' TECHN ICAL SUPPORT FOR DESIGN. CONSTRUCTION. OPERATION. AND PERFORMANCE REVIEWS FOR LOW LEVEL WASTE," JOB CODE 12094

Deaf $\mathrm{Hr}$. Cumesty:

This letter is to request a proposal for performance of the enclosed modiffcation to Task Order 7 under Job Code L2094 for the Nuclear Regulatory Commission. Office of Nuclear Material Safety and Safeguards. The enclosed modification details the required work and should be used as the basisfor proposal preparation.

\section{Cost Proposal}

The task order proposal should contain the cost information as is reguired on the NRC Form 189, "DOE Laboratory Project and Cost Proposal for NRC Work."

A spending plan should also be submitted as part of your cost proposal. Guidance for completion of the plan is contained in the instructions portion of the NRC Form 189.

\section{Technical Proposal Content}

As a minimum, the technical proposal must contain the following:

- A discussion to substantiate the laboratory's understanding of the scope of work.

- A discussion of the laboratory's technical approach to meet the project's objective.

- A discussion of the experience and capabilities of key personnel and the laboratory in performing simi lar work.

Identffication of key personnel and the number of staff haurs that will be comitted to completion of work. Resumes for key personnel must be included.

- Identiffcation of adninistrative support personnel and/or facitities needed to assist professional personnel in completing work.

- A discussion of any potential organizational confilct-of-interest i ssues. 


\section{E. Cumesty}

A discussion of antfcipated problem areas or deviations from the NRC's statement of work.

Th1s request for proposal is an authorization to start work, Authorization to begin work vfa an NRC form 173 "Standard Order for DOE Work" is enclosed.

Work under this project Is anticipated to be unclassified.

Performance of work under this modification to Task Order 7 is urgently required in support of the Dlvfsion of Waste Management and, in accordance with NRC ManagementDirective 11.7 . expedited handling by both DOE and the laboratory is hereby requested, The proposal should be faxed to the NRC not later than November 24. 1997. Please advise the individual mentioned below by telephone if there is any difficulty in meeting this due date,

The proposal should be sent in an original and two copies to the Nuclear Regulatory Commission. ATTN: Deborah DeMarco. Office of Nuclear Material Safety and Safeguards. Mai1 Stop T8A23. Washington. DC 20555.

Questionsconcerning this request should be addressed to Deborah Delarco on 301-415-7796. Thank you far your assistance in this matter.

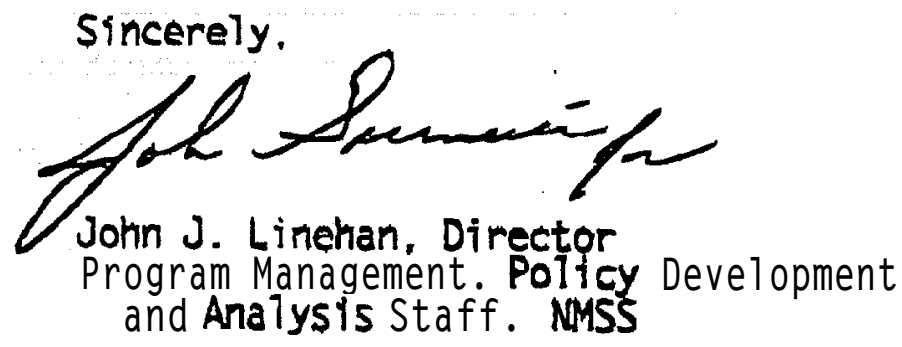

EncTosure: SOEN 5098008

cc; D. Cooper, OR

c. Puan. ORNL

J. Simoson, ORNL

L. MeCold, ORNL 

NROW 11.7 STANDARD ORDER FOR DOE WORK (SOEW)

ORDER NUMMER

5098008

DATE OF ISSUANC:

Kovember 18,1997

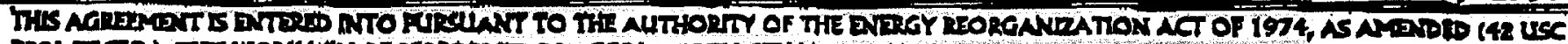

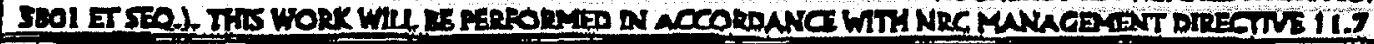

ISSUIP TO: (DOE Otike)

Oak RJdore Operndons Onion

PERFORMING ORGANIZATION

Ouk Rid - National Lubormory

Ook Ride, Temeon

JOB CODE ITTE

Tectuiesl Supdore for Delon, Consurtion,

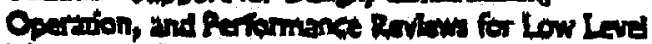
Waste Fer Reconesble
ISSUED BY: (NRC OHiCe) OFFICE OF NUCLEAR MATERIAL SAFETY AND SAFEGUARDS (NMSS)

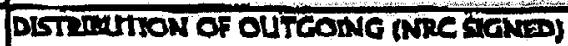

D. Derineo

1. Holonich

M. Fliezel

C Abbos

K. Mropty

L-2094

DiSTbULUTION OF RCORANG (DOE IGNDD)
Accounmig aTANION

APPROPRITION ShMOL $31 \times 0200$

BNR NUMBER

85015123015

JOB CODE

L2094

8OCCODE

$25 \mathrm{ID}$

PROJECT PEPFORM. PERIOD

\begin{tabular}{l|l}
\hline Beon & BND
\end{tabular}

\begin{tabular}{l|l} 
cont & $12 / 31 / 99$ \\
\hline
\end{tabular}

THIS $\boldsymbol{X}$ FUNDING PENOD

FEOM

$8 / 11 / 97$

$12 / 51 / 97$

OBLIGATION AVAILABILITY PROVDED BY

A THIS ORDER

B. TOTAL OF ORDERT FRIOR TO THISDATEWIH THEPERFORIMING ORGANIZATION UNDER THIS JOB CODE FOR THIS FY

C. TOTAL ORDERS TO DATE FOR THIS JOB CODE FOR THIS $Y(A+B)$

50.00

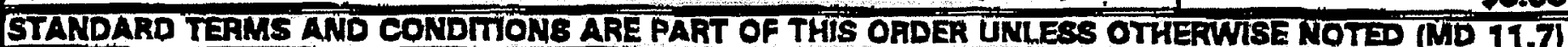

-

ATTACHMENTS

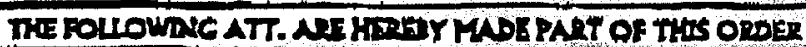

ITATERT OF wopK

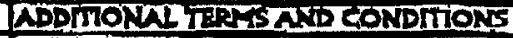

OTtion

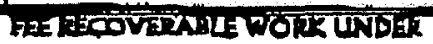

IO GTPART 170

res ERAM IBY ISADACHFA.

SECURTY

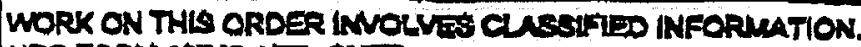
NRC FORM TAT IS ATTAOHIED.

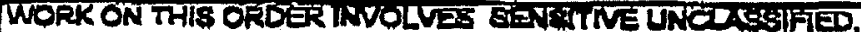
UNCLASBIFIED SNFEGUAPDS INFORMATION OR UNESCORTE ACCESS AND VTLL AREAS OF NUCLEAR FOWER PLANTR NRC

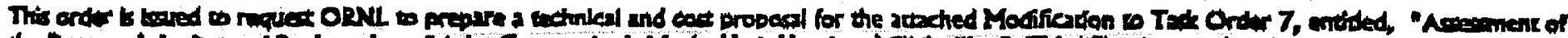

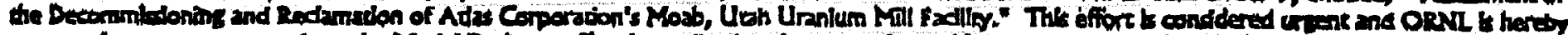

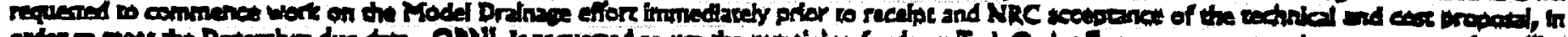

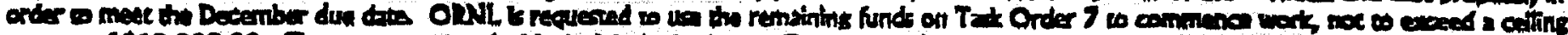

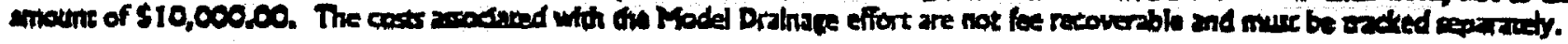

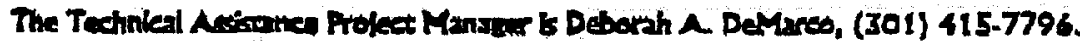

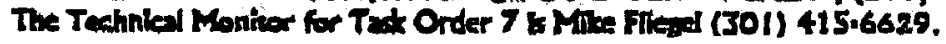

\section{CERTIFICATION OF FUNDS}

THIS CERTIFES THAT FUNDS $N$ THE AMOUUNT CITED IN BLOCK A ARE AVAILABLE IN THE CLRRENT

FY ALIOTMENT ROR WORK AUTHOYYZAD BY THIS SOEW.

FUNDS CERTIFICATION OFFICAL (TTPED NANAA)

Deborah A Dekaro

Nor Abelleable

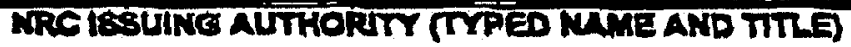

IOHN I. LNEEYAN DIRECTOR, PMDA NMSS

DOE ACCZPTING OREANESTIONTMPAD NAME AND TITLE)

\begin{tabular}{|l|l|}
\hline SIGNATURE & DATE \\
\hline SIGY TRRE & DATE $/ \mathrm{rA} / \mathrm{m}$ \\
\hline SIGNATURE & DATE \\
\hline
\end{tabular}


MODIFICATION 1 TO TASK ORDER 7

PROJECT TITLE:

-DOCKET NUMBER:

TAC NUMBER:

NRC OFFICE;

NRC PROJECT MANAGER:

NRC TECH. MONITOR:
Assessment of the Deconmissioning and Reclamation of Atl as Corporation's Moab. Utah Urani um M\{11 Facility 04003463

L2094

NMSS

Deborah Deharco, 301-415-7796

Myron Filege1, 301-415-6629

\section{1. $\varnothing$ Backoround}

Atlas Corporation (Atlas) owns a uranium mill tailings impoundment containing approximately 10.600 .000 cublc yards of AEA 11 e. (2) byproduct material at the former location of it's uranium mlliing facility near hoab. Utah. Atlas is currently requesting a license amendment to reclaim the tatiings In-place in accordance with NRC regulations in 10 CFR 40. Appendix A. At las developed a closure plan with a disposal cell design, based a on design life to be effective for 1.000 years to the extent reasonably achfevable, and in any case at Jeast 200 years.

NRC staff evaluated the environmental and safety considerations of the proposed design and issued a Final Technical Evaluation Report (NLREG-1532) and a Draft Environmental Impact Statement (NUREG-1531). The staff must complete its envi ronmental review and issue the Final Environmental Impace Statement (FEIS) before it can render its decision on Atlas' proposal. The remaining plece of information that the staff needs to complete the FEIS is a Biological Opinion of the proposed federal action, by the U.S. Fish and Wildlife Service (FWS), in accordance with the Endangered Spectes Act.

The FWS issued a draft Blological Opinion, which outlined several concerns with the proposed action. FWS has stated that additional tests and analysis are needed for the biafogical opinion. All. but one of these are to be managed by FWS. In meetings with the Council on Environmental Qual ity and the Department of the Interior. NRC agreed to fund one task (designated Task 5). The task address - a Fws concern related to the predicted long-term seepage evaluation presented in the EIS. The model is designed to perform addr tional analysis of the long-term seepage from the taflings pile. based on the proposed in-place design.

\subsection{Objectsve}

The overall objective is to assist the NRC in evaluating the long-tem seepage potential, through the closure design life. from the proposed in-place closure design of the Atlas Uranium Hill Tailings pile nearMoab. Utah. 


\section{2}

\subsection{Iechnical and Other Snectal Oualifications Requrced}

ORNL shal1 comnit the appropriate number of qualified staff to the project encompassing the required disciplines to perform the above described objective. NRC reserves the right to approve the Project Manager and the . individual personnel assigned to the Task from the necessary technical discipline. which is ground-water hydrology. The ORNL Project Manager shall be experienced in managing modeling projects including documentation of modeling effort and the results. and may not be changed during the project without prior written approval by NRC,

\subsection{Level of Effort}

The staff estimates the level of effort to be approximately 3 to 4 staff weeks, with the following breakdown:

Mode1 Drainage

Subtask A

Subtask B

Subtask C

Subtask D
I staff week

I to 2 staff weeks

1 staff day

I staff week

\subsection{Completion Dates}

Mode1 Drainage

January 9. 1998

Subtask $A$

December 5, 1997

Subtask B

December 24. 1997

Subtask C

December 17. 1997

Subtask D

January 9. 1998

\subsection{Work Reauired}

Use an appropriate computer code to construct a model of the Atlas Tailings pile and evaluate the long-term seepage from the tallings pile. based on the proposed in-place closure design. The code should be sufficiently robust to 
simulate both saturated and unsaturated flow condtions in the cover. tailings materials, and subgrade.

\section{Subtask $A$}

Assentie a team and compile pertinent data. Data sources for the input parameters w117 include data and information contained in the NRC central files for docket 40-3453. site-specific information provided by Atlas Corporation. and public-domafn sources- The contractors shal1 notify NRC by telephone when work begins on this task.

Complete this subtask by December 5, 1997.

\section{Subtask B}

Construct a model of the Atlas tailings pile and evaluate the longterm seepage from the tailingspile, based on the proposed In-place closure design. The model dome in will incorporate a two-dimensi onal vertical view of the tailings pile wfth appropriate materlal properties assigned to the cover, taifings.and subgrade components.

Input parameters will be based on proposed desfgn specifications for the cover. realisticestimates of tailings properties based on existing site-spcclflc information and generally applicable material properties 'from other taitings piles. and realistic esffmates of subgrade properties. The hydrautic conductivity of the radon barrier component of the cover shall be initially simulated by the design permeability of $1 \times 10 " \mathrm{~cm} / \mathrm{sec}$. and again with a permeability of $1 \times 10^{-8} \mathrm{~cm} / \mathrm{sec}$. Subgrade properties. such as hydraulte conductivity, will be based on material descriptions from existing borings and confirmed by historical hydraulic headinformation within the tailings pile from the operational and post-operational time periods. Seepage outputs will be expressed as a flux from the area beneath the tailings pile. expressed in gallons per minute.

Complete the subtask, by December 24. 1997.

\section{Subtask C}

Averbal progress report shall be made approximateiy mid-way through this task. The verbal report shall out ine the current status of the task. projected completion dates, any difficulttes encountered 
to date. and any preliminary findings. Any additional verbal reports wiTl be determined by NRC. based on the schedule forecasts from the initial verbal report. Verbal reports will be made by conference call to the NRC and may include representatives from the U.S.Fish and Witdlife Service. and Atlas Corporation.

Complete 1nitial verbal report for this subtask by December 5, 1997.

\section{Subtask $\cdot D$}

Upon completion of the computer modeling. a written report shall be provided which documents the assumptions and bases of the computer model development. data and information used to represent site conditions, the various simulations performed, and the results of those simulation's.

Complete the subtask, by January 9,1998.

$7 . \emptyset$ Maetinas and Travel

No meetings or travel are required for this task.

\subsection{NRC Fumished Matertal}

NRCWTl1 provide the following to ORNL:

Coptes of boring logs. maps of boring locations. design drawings of the tailings disposal cel 1 . NRC will arrange Portransfer of operational and post-operational water level information from Atl as Corporation.

\subsection{DOE ACquired Material}

Nomaterials are expected to be acquired under this task order.

\subsection{Schedule}

The schedule for the various Subtasks are stated in Section 5.0.

\subsection{Reports}

The final report will be a written report of the seepage evaluation over the long-term design iffe of the Atlas Uranium M117 Tailings disposal cel1. The report shall describe the computer code used, document. the assumptions and 
bases used to develop of the computer model. data and infomation used to represent site conditions and model input, the various simulations performed. and the results of those simutations.

A monthly letter report (MLR) sha11 be prepared by the 20 th of the following month.. The following breakdown of monthly staff utilization shall be provided in the MLR for each task showing the number of hours charged to the following categories; ground-water hydrology, and project management. The report shall describe by these categories. the work activities accomplished and in progress with an estimate of the degree of completeness. Completion dates should be tracked and reported on the Subtask level.

\subsection{Iechnical Direction}

Myron FTiegel is designated as the NMSS Technical Monitor for the seepage modeling task of the Atlas Uranium Mill Tallings closure design. Deborah DeMarco is designated as the NRCProject Manager. Technical instructions may not constitute new assignments of work or changes of such anature as to justify an adjustment in cost or period of performance. Directions. 1f any, for changes in scope of work. cost. or period of performance will be issued by the NRC Project Manager. 